\title{
An Asymmetric Archaebacterial Diether Lipid from Alkaliphilic Halophiles
}

\author{
By M. DE $\operatorname{ROSA}^{1}$ A. GAMBACORTA, ${ }^{1}$ B. NICOLAUS, ${ }^{1}$ \\ H. N. M. ROSS, ${ }^{2}$ W. D. GRANT ${ }^{2 *}$ AND J. D. BU'LOCK \\ ${ }^{1}$ Istituto di Chimica di Molecole di Interesse Biologica, C.N.R., Via Toiana, Arco Felice, \\ Napoli, Italy \\ ${ }^{2}$ Department of Microbiology, School of Medicine and School of Biological Sciences, \\ University of Leicester, Leicester LE1 7RH, U.K. \\ ${ }^{3}$ Department of Chemistry, University of Manchester, Manchester M13 9PL, U.K.
}

(Received 28 August 1981)

Archaebacterial halophiles from alkaline soda lakes were shown to possess substantial amounts of a core diether lipid differing from the $\mathrm{C}_{20}, \mathrm{C}_{20}$ diether lipid characteristic of Halococcus and Halobacterium spp. This novel diether lipid was shown to be an asymmetric $\mathrm{C}_{20}, \mathrm{C}_{25}$ diether (2-O-sesterterpanyl-3-O-phytanyl-sn-glycerol). The implications of this unusual lipid for membrane structure are discussed.

\section{INTRODUCTION}

Extremely halophilic bacteria of the genera Halobacterium and Halococcus, the methanogens and the thermoacidophilic genera Sulfolobus and Thermoplasma have been designated members of the urkingdom Archaebacteria based on sequencing studies of $16 \mathrm{~S}$ rRNA (Magrum et al., 1978; Woese et al., 1978). Archaebacteria characteristically lack

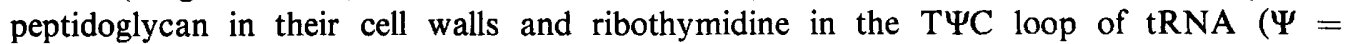
pseudouridine). Equally characteristic of all the archaebacteria whose lipids have so far been described is a cell membrane based on unusual ether-linked isopranyl lipids (De Rosa et al. 1977b, 1980a; Langworthy, 1977; Langworthy et al., 1974; Makula \& Singer, 1978). Among the halophiles, Halobacterium and Halococcus spp. possess only $\mathrm{C}_{20}, \mathrm{C}_{20}$ glycerol diethers (Kates, 1976), but the recently described alkaliphilic red halophiles (Tindall et al., 1980; Ross et al., 1981) have been shown to possess an additional ether lipid component which is chromatographically distinct from the well-characterized $\mathrm{C}_{20}, \mathrm{C}_{20}$ glycerol diether (Ross et al., 1981). We report here that this novel ether lipid component is a glycerol diether with one $C_{20}$ phytanyl chain and one $C_{25}$ 'sesterterpane' $(2,6,10,14,18$-pentamethyleicosane) chain.

\section{METHODS}

Cultures. Alkaliphilic halophile strains SP1, SP2 and MS3 (Ross et al., 1981) were grown in liquid medium as previously described (Tindall et al., 1980). Cultures were harvested in the early-stationary phase of growth by centrifugation and were freeze-dried. After screening lipid extracts of the strains for the presence of the new compound (Ross et al., 1981), strain MS3 was chosen for further investigation as it contained the greatest amount.

Extraction and hydrolysis of lipids. Dried cells were extracted continuously by the Soxhlet process for $12 \mathrm{~h}$ with chloroform/methanol $(1: 1, \mathrm{v} / \mathrm{v})$. The total lipid extract, about $8 \%$ of the lyophilized cells, was treated with methanolic $\mathrm{HCl}$ for $6 \mathrm{~h}$ under reflux (De Rosa et al., 1977b). The hydrolysate was dried in vacuo.

Purification and characterization of diethers. The preliminary purification of diethers in the hydrolysate was performed on a silica gel 60 column [Merck, 230-400 mesh: $30 \mathrm{~mm}$ (i.d.) $\times 450 \mathrm{~mm}$ ] eluted with $\mathrm{CHCl}_{3}$ and $\mathrm{CHCl}_{3} / \mathrm{Et}_{2} \mathrm{O}(95: 5, \mathrm{v} / \mathrm{v})$. The diether fraction was further resolved into 2,3-di- $O$-phytanyl-sn-glycerol and the 
unknown diether by high performance liquid chromatography (Waters Associates) in $n$-hexane/ $\mathrm{Et}_{2} \mathrm{O}(95: 5, \mathrm{v} / \mathrm{v})$, using Microporasil columns $\left(3.9 \mathrm{~mm} \times 30 \mathrm{~cm}\right.$, flow rate of $2 \mathrm{ml} \mathrm{min}^{-1}$ for analytical work; $7.8 \mathrm{~mm} \times 30 \mathrm{~cm}$, flow rate $6 \mathrm{ml} \mathrm{min}{ }^{-1}$ for preparative work).

Molecular weight determinations were performed by vapour pressure osmometry in $\mathrm{CHCl}_{3}$ using a Perkin-Elmer Hitachi model 115 instrument (De Rosa et al., 1980a). Infrared spectra of diethers were recorded using a Perkin-Elmer 257 spectrophotometer and optical rotations were measured in $\mathrm{CHCl}_{3}$ using a Perkin-Elmer 115 polarimeter (De Rosa et al., 1980a). ${ }^{1} \mathrm{H}$-n.m.r., ${ }^{13}$ C-n.m.r. and mass spectra were recorded as described by De Rosa et al. (1977b). Gas chromatography/mass spectrometry of diether acetates was performed as described by De Rosa et al. $(1977 b)$ with a temperature programme of $180-300^{\circ} \mathrm{C}$ at $10^{\circ} \mathrm{C} \mathrm{min} \mathrm{m}^{-1}$. Other gas-liquid chromatography (g.l.c.) analyses were performed as described by De Rosa et al. $(1977 \mathrm{~b})$ with a temperature programme of $120-280^{\circ} \mathrm{C}$ at $10^{\circ} \mathrm{C} \mathrm{min}$ m $^{-1}$ for isopranoid acetates and at $300^{\circ} \mathrm{C}$ for diether acetates. Acetylation and $\mathrm{BCl}_{3}$ cleavage of the unknown diether were performed as described by De Rosa et al. (1980a). Isopranoid iodides and acetates were produced by the methods of De Rosa et al. (1976, 1977b).

\section{RESULTS}

The lipid content of the alkaliphilic halophile strains was about $8 \%$ of the dry cell weight. Hydrolysis of the complex lipids gave rise to a mixture of two glycerol isopranoid diethers, in which the unknown diether represented $55 \%(\mathrm{w} / \mathrm{w})$ of the mixture $(8.5 \%$, w/w, of the total lipid extract). The optical rotation $\left([\alpha]_{\mathrm{D}}=+7 \cdot 2\right)$ and the infrared spectra of the unknown were almost identical to those for the well-characterized 2,3-di- $O$-phytanyl-sn-glycerol (Kates, 1976; Ross et al., 1981).

G.l.c. analysis of the isopranoid acetates derived from the unknown showed two equivalent peaks with retention times of 6.9 and $12.2 \mathrm{~min}$, respectively. Gas chromatography/mass spectrometry of these two peaks yielded cleavage patterns characteristic of a $\mathrm{C}_{20}$ and a $\mathrm{C}_{25}$ isopranoid acetate, respectively: $\left[\mathrm{C}_{22} \mathrm{H}_{44} \mathrm{O}_{2}, m / e 340\left(\mathrm{M}^{+}\right), 280\left(\mathrm{M}^{+}-\mathrm{AcOH}, 12 \%\right), 252\right.$ (4), 210 (10), 196 (20), 182 (10), 140 (40), $126(80), 125$ (100); $\mathrm{C}_{27} \mathrm{H}_{54} \mathrm{O}_{2}, \mathrm{~m} / \mathrm{e} 410\left(\mathrm{M}^{+}\right)$, 350 ( $\left.\mathrm{M}^{+}-\mathrm{AcOH}, 15 \%\right), 322$ (3), 280 (6), 266 (10), 252 (6), 210 (14), 196 (31), 182 (9), 140 (45), $126(77), 125$ (100)]. G.l.c. analysis of the isopranoid monochlorides produced by $\mathrm{BCl}_{3}$ cleavage indicated that the two monochlorides were in an equivalent molar ratio with glycerol (glycerol: $\mathrm{C}_{20}: \mathrm{C}_{25}=0 \cdot 98: 0 \cdot 97: 1 \cdot 1$ ). ${ }^{1} \mathrm{H}$-n.m.r. spectra of the monoacetylated diether indicated a signal due to $\mathrm{CH}_{2} \mathrm{OAc}$ protons $(\delta 4 \cdot 14)$ coupled with a single $\mathrm{CHO}$ proton signal $\left(\delta 3.5\right.$, coupled and overlapping with a single $\left.\mathrm{CH}_{2} \mathrm{O}\right)$. These data establish the substitution of the $\alpha$ and $\beta \mathrm{OH}$ groups of the glycerol moiety by the ether linkages, but do not establish the relative location of the two different $\left(C_{20}\right.$ and $\left.C_{25}\right)$ chains, nor do they preclude the presence of a mixture of diethers rather than a single molecular species. Mass spectra of the acetylated $\mathrm{C}_{20}, \mathrm{C}_{25}$ glycerol diether showed a peak at $m / e 705$ (loss of the acetyl group). At $m / e$ values higher than 250 there were three critical peaks associated with the loss of aliphatic chains linked at the $\alpha$ or $\beta$ glycerol carbons. Peaks at $m / e 453$ and 467 are related to the loss of $-\mathrm{CH}_{2}-\mathrm{O}-\mathrm{C}_{20} \mathrm{H}_{41}$ and $-\mathrm{O}-\mathrm{C}_{20} \mathrm{H}_{41}$, respectively, and the former, in particular, showed that the $\mathrm{C}_{20}$ residue is located on the $\alpha$ glycerol carbon, whilst the peak at $m / e 397$, associated with loss of $-\mathrm{O}-\mathrm{C}_{25} \mathrm{H}_{51}$, places this residue on the $\beta$ carbon (Fig. 1a). The absence of a peak of significant size at $m / e 383$ showed that these locations are unique.

Confirmatory mass spectra of the alkyl monoacetates showed molecular ions corresponding to $\mathrm{C}_{20}$ monoacetate $(\mathrm{m} / \mathrm{e} 340), \mathrm{C}_{25}$ monoacetate $(\mathrm{m} / \mathrm{e} 410)$, and fragments at $\mathrm{m} / \mathrm{e} 280$ and 350 which correspond to the same fragments after loss of $\mathrm{AcOH}$. Both spectra revealed a regular series of cleavage products representing sequential loss of saturated isoprene units. Other series of cleavage products, relating to the loss of methyl groups, indicated the same pattern of location of these groups in the $\mathrm{C}_{25}$ monoacetate as in the $\mathrm{C}_{20}$ monoacetate. The major fragments of the $\mathrm{C}_{25}$ monoacetate $(\mathrm{m} / \mathrm{e} 126,182,196,252,266,322$ and 337) indicated the presence of a regular 'head-to-tail' structure; a 'tail-to-tail' condensation as in the $\mathrm{C}_{25}$ isomer 2,6,10,15,19-pentamethyleicosane can be ruled out as this compound does not produce an $m / e 252$ peak, whereas it does give a major fragment at $m / e 309$ which is absent in the fragmentation of the naturally derived $C_{25}$ acetate (Holzer et al., 1979). Accordingly, 


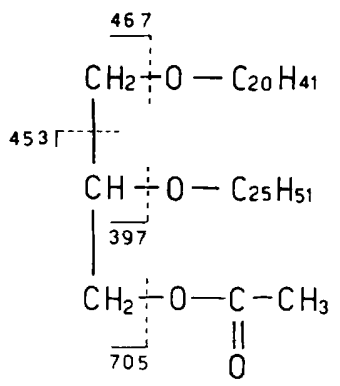

(a)<smiles>CC(=O)OCC1COC(=O)OC1</smiles>

(c)

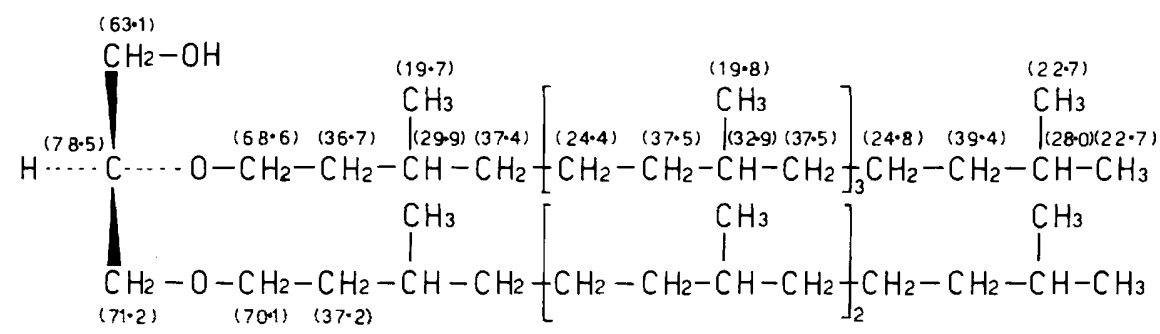

(b)

Fig. 1. Mass spectrographic and n.m.r. analysis of glycerol diether. (a) Structure of the acetylated $\mathrm{C}_{20}, \mathrm{C}_{25}$ glycerol diether indicating the characteristic mass spectral cleavage pattern due to the position of the $\mathrm{C}_{25}$ isopranoid on the $\mathrm{C}-2$ of glycerol (see text). (b) Structure of 2-O-sesterterpanyl3-O-phytanyl-sn-glycerol showing characteristic ${ }^{13} \mathrm{C}$-n.m.r. chemical shifts, indicating a 2,3dialkoxypropan-1-ol structure with regular 'head-to-tail' isopranoid chains. (c) Structure of 2,3di- $O$-phytanyl-sn-glycerol, for comparison.

we believe that this isopranoid has the regular 2,6,10,14,18-pentamethyleicosane (sesterterpane) skeleton.

${ }^{13} \mathrm{C}$-n.m.r. spectra of the $\mathrm{C}_{20}, \mathrm{C}_{25}$ diether (all signals and multiplicities assigned, Fig. $1 \mathrm{~b}$ ) confirmed a 2,3-dialkoxypropan-1-ol structure with regular 'head-to-tail' isopranoid chains; vapour pressure osmometry on the new diether indicated a molecular weight of 729 $\left(\mathrm{C}_{48} \mathrm{H}_{98} \mathrm{O}_{3}=722\right)$.

These results establish the structure of the new ether lipid as that shown in Fig. $1(b)$. This differs from the well-known 2,3-di-O-phytanyl-sn-glycerol (Fig. $1 c$ ) in having a $\mathrm{C}_{25}$ saturated isoprenoid chain in place of the phytanyl residue at C-2.

All of our isolates of red halophiles from alkaline soda lakes, such as Lake Magadi in Kenya and the Wadi Natrun in Egypt, have afforded substantial proportions of this new diether lipid in addition to the usual 2,3-di-O-phytanyl-sn-glycerol $(\mathrm{H}$. N. M. Ross \& W. D. Grant, unpublished results).

\section{DIS CUSSION}

Archaebacteria exhibit a considerable range of diversity within the basic scheme of ether lipids, reflected to some extent in morphology, cell wall type and habitat (Balch et al., 1979; Woese et al., 1978). Until now, the lipids have all proved to be based either on 2,3-di-O-phytanyl-sn-glycerol (glycerol with two ether-linked $\mathrm{C}_{20}$ chains) (De Rosa et al., $1977 a, b, 1980 a$; Kates, 1976) or, in the thermoacidophiles and some methanogens, on a type of diglycerol di-biphytanyl tetraether, in which two such $\mathrm{C}_{20}, \mathrm{C}_{20}$ diether moieties are linked 'head-to-head' to give $\mathrm{C}_{40}, \mathrm{C}_{40}$ (di-biphytanyl) units which may also be partly cyclized 


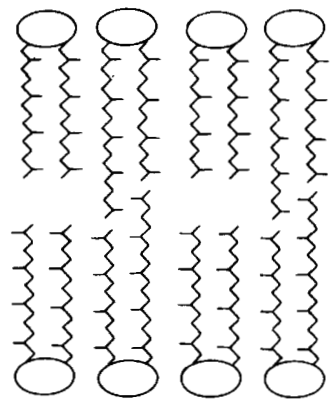

(a)

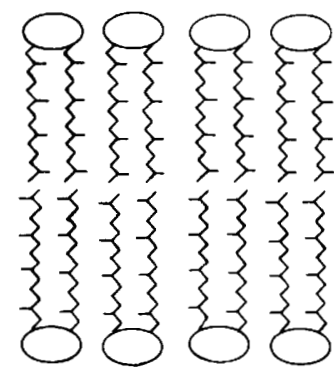

(c)

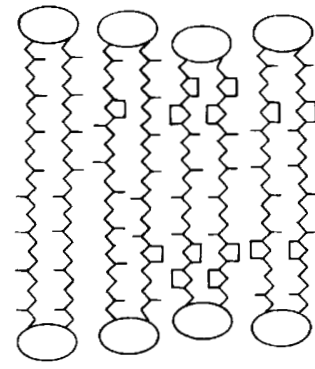

(b)

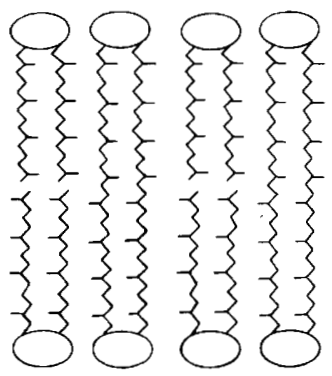

$(d)$

Fig. 2. Proposed archaebacterial membrane types. (a) 'Zip' membrane formed by $\mathrm{C}_{20}, \mathrm{C}_{25}$ and $\mathrm{C}_{20}, \mathrm{C}_{20}$ diether lipids proposed for alkaliphilic halophiles. (b) Rigid monolayer membrane structure formed by $\mathrm{C}_{40}, \mathrm{C}_{40}$ tetraether lipids including cyclized forms proposed for the thermoacidophiles $S$ ulfolobus and Thermoplasma (De Rosa et al., 1980b). (c) Bilayer membrane formed by the $\mathrm{C}_{20}, \mathrm{C}_{20}$ diether lipids proposed for Halobacterium and Halococcus spp. and some methanogens (Kates, 1976; Balch et al., 1979). (d) Mixed membrane structure formed by a mixture of $C_{20}, C_{20}$ diethers and $C_{40}, C_{40}$ tetraethers proposed for some methanogens (Balch et al., 1979).

(De Rosa, 1977b, 1980a; Makula \& Singer, 1978; Tornabene \& Langworthy, 1978). This is the first report of an archaebacterium possessing asymmetric ether lipids. However, several $\mathrm{C}_{25}$ isopranoids including 2,6,10,14,18-pentamethyleicosane have been reported as constituents of various oils, shales and sediments, sometimes in significant amounts (Brassell et al., 1981). $\mathrm{C}_{25}$ isopranoids, in particular the isomer 2,6,10,15,19-pentamethyleicosane, have also been described as components of the neutral lipid fraction of certain methanogens (Tornabene et al., 1979), while 2,6,10,14,18-pentamethyleicosane has been detected in small amounts in the neutral lipid fraction of Sulfolobus and Thermoplasma (Holzer et al., 1979). However, none of these $C_{25}$ isopranoids has previously been detected in ether linkages with glycerol, and it is not clear if these isopranoid hydrocarbons are intermediates or degradative products of larger isopranoids.

In the membrane of the alkaliphilic archaebacteria, strong and unusual interactions are expected to occur between alkyl chains located in opposite faces of the lipid bilayer owing to major penetration by the longer $\mathrm{C}_{25}$ chains into the opposite lipid layer, effectively causing a 'zip' effect in the middle of the membrane. Such a type of lipid organization, as illustrated in Fig. 2(a), may be intermediate in stability between the rigidly bridged $\mathrm{C}_{40}, \mathrm{C}_{40}$ tetraether monolayer structure found in thermoacidophiles (Langworthy, 1978; De Rosa et al., $1980 \mathrm{~b}$ ) (Fig. $2 b$ ) and the regular bilayer formed by $\mathrm{C}_{20}, \mathrm{C}_{20}$ diethers found in Halobacterium and Halococcus spp. (Kates, 1976). It may be similar in stability to the mixed $\mathrm{C}_{20}$ and $\mathrm{C}_{40}$ 
membrane structure found in certain methanogens (Fig. 2d) (Rohmer et al., 1979), but the 'zip' structure could imply a slightly thicker membrane with gaps at some points between the $\mathrm{C}_{20}$ chains. However, the length of the isopranoid chains may not be the sole factor in determining membrane dimensions; for example, the cyclized isopranoid units reported in the thermoacidophiles (De Rosa et al., $1980 \mathrm{~b}$ ) presumably would result in a $\mathrm{C}_{40}$ chain which is shorter than in their uncyclized congeners (Fig. $2 b$ ).

The biochemistry of the alkaliphiles remains largely unexplored and these bacteria are particularly interesting in that they cope with the dual stress of high salt concentrations and very high $\mathrm{pH}$. The occurrence of these asymmetric lipids may be a significant feature of membrane stability under these exceptional conditions. However, at least one Halobacterium sp. has also been found to have a chromatographically similar lipid component (Ross et al., 1981). It is possible that this particular strain has a high pH optimum and it remains to be established whether the asymmetric polar lipids are restricted to alkaliphilic or alkalitolerant isolates.

It is widely held that $\mathrm{C}_{20}$ and $\mathrm{C}_{40}$ isopranoids in kerogen, sediments and oils derive, in part at least, from the membranes of archaebacteria. This report of an extant archaebacterium with large amounts of $\mathrm{C}_{25}$ isopranoids in its membranes strongly supports the suggestion of a similar origin for the $\mathrm{C}_{25}$ compounds found in the same deposits. We still await the discovery of the 'archaebacterial coelacanth' containing ethers based on the $C_{15}$ isopentadecane described in the Messel kerogen by Chappe et al. (1979).

\section{REFERENCES}

Balch, W. E., Fox, G. E., Magrum, C. R., Woese, C. R. \& Wolfe, R. S. (1979). Methanogens: reevaluation of a unique biological group. Microbiological Reviews 43, 260-296.

Brassell, S. C., Wardroper, A. M. K., ThOMSON, I. D., Maxwell, J. R. \& Eglinton, G. (1981). Specific acyclic isoprenoids as biological markers of methanogenic bacteria in marine sediments. Nature, London 290, 693-696.

Chappe, B., Michaelis, W., Albrecht, P. \& Ourisson, G. (1979). Fossil evidence for a novel series of archaebacterial lipids. Naturwissenschaften 66, 522-523.

De Rosa, M., Gambacorta, A. \& Bu'lock, J. D. (1976). The Caldariella group of extreme thermoacidophilic bacteria: direct comparison of lipids in Sulfolobus, Thermoplasma and the MT strains. Phytochemistry 15, 143-145.

De Rosa, M., De Rosa, S. \& Gambacorta, A. $(1977 a) .{ }^{13} \mathrm{C}-\mathrm{NMR}$ assignments and biosynthetic data for the ether lipids of Caldariella. Phytochemistry 16, 1909-1912.

De Rosa, M., De Rosa, S., Gambacorta, A., Minale, L. \& Bu'lock, J. D. (1977b). Chemical structure of the ether lipids of thermophilic acidophilic bacteria of the Caldariella group. Phytochemistry 16, 1961-1965.

De Rosa, M., De Rosa, S., Gambacorta, A. \& Bu'LOCK, J. D. (1980a). Structure of calditol, a new branched-chain nonitol, and of the derived tetraether lipids in thermoacidophile archaebacteria of the Caldariella group. Phytochemistry 19, 249-254.

De Rosa, M., Esposito, E., Gambacorta, A., Nicolaus, B. \& Bu'LOCK, J. D. $(1980 b)$. Effects of temperature on ether lipid composition of Caldariella acidophila. Phytochemistry 19, 827831 .
Holzer, G., Oro, J. \& Tornabene, T. G. (1979). Gas chromatographic-mass spectrometric analysis of neutral lipids from methanogenic and thermoacidophilic bacteria. Journal of Chromatography 186, 795-809.

KATES, M. (1976). Ether-linked lipids in extremely halophilic bacteria. In Ether Lipids, Chemistry and Biology, pp. 351-398. Edited by F. Snyder. New York: Academic Press.

LANGwORTHY, T. A. (1977). Long chain diglycerol tetraethers from Thermoplasma acidophilum. Biochimica et biophysica acta 487, 37-50.

LANGWORTHY, T. A. (1978). Membranes and lipids of extremely thermoacidophilic microorganisms. In Biochemistry of Thermophily, pp. 11-30. Edited by S. M. Friedman. New York: Academic Press.

LANGWorthy, T. A., MaYberRy, W. R. \& SMith, P. F. (1974). Long chain diether and polyol dialkyl glycerol triether lipids of Sulfolobus acidocaldarius. Journal of Bacteriology 119, 106-116.

Magrum, L. J., Luehrsen, K. R. \& Woese, C. R. (1978). Are extreme halophiles actually "bacteria"? Journal of Molecular Evolution 11, 1-8.

Makula, R. A. \& Singer, M. E. (1978). Ethercontaining lipids of methanogenic bacteria. Biochemical and Biophysical Research Communications 82, 716-722.

Rohmer, M., Bouvier, P. \& Ourisson, G. (1979). Molecular evolution of biomembranes; structural equivalents and phylogenetic precursors of sterols. Proceedings of the National Academy of Sciences of the United States of America 76, 847-851.

Ross, H. N. M., Collins, M. D., Tindall, B. J. \& GRANT, W. D. (1981). A rapid procedure for the detection of archaebacterial lipids in halophilic bacteria. Journal of General Microbiology 123, 75-80. 
Tindall, B. J., Mills, A. A. \& Grant, W. D. (1980). An alkalophilic red halophilic bacterium with a low magnesium requirement from a Kenyan soda lake. Journal of General Microbiology 116, 257-260.

Tornabene, T. G. \& LANGWorThy, T. A. (1978). Diphytanyl and dibiphytanyl glycerol ether lipids of methanogenic archaebacteria. Science 203, 51-53.

Tornabene, T. G., Langworthy, T. A., Holzer, G.
\& Oro, J. (1979). Squalenes, phytanes and other isoprenoids as major neutral lipids of methanogenic and thermoacidophilic archaebacteria. Journal of Molecular Evolution 13, 73-83.

Woese, C. R., Magrum, L. J. \& Fox, G. E. (1978). Archaebacteria. Journal of Molecular Evolution 11, 245-252. 